\title{
Liana Allan
}

\section{Reforming capital in
taxation to improve
affordability}

New Zealand's distortionary tax environment for housing imposes large costs on young people. Since 1989, New Zealand has taxed owner-occupied housing more lightly than other forms of capital income. In contrast, retirement savings have been taxed heavily. This combination has created a bias towards owner-occupied housing, encouraging homeowners to live in higher quality properties than they would under a neutral tax system, and bid up the price of land located near desirable amenities.

While existing, often older homeowners have enjoyed high land and house values, our generation has faced artificially inflated house prices. Distortionary capital income taxation has contributed to New Zealand's housing affordability crisis.
Forms of capital income taxation Capital income can be taxed on three bases: exempt-exempt-tax (EET), tax-exemptexempt (TEE) (both expenditure taxes), and tax-tax-exempt (TTE) (an income tax). Most OECD countries adopt an EET scheme for retirement savings. Under this scheme, income is not taxed when it is earned or accumulating in a retirement savings fund, but instead taxed when the balance is withdrawn at retirement.

Owner-occupied housing in New Zealand is taxed on a TEE basis. This means income used to purchase a house is taxed when it is earned, but imputed rent and capital gains are not taxed. New Zealand taxes retirement savings in KiwiSaver, rental properties, shares and other assets on a TTE basis. This means income is taxed 
when it is earned and as it accumulates, but not when it is withdrawn and spent. To tax capital income neutrally, a country needs to tax retirement income accounts on a TTE basis, tax all capital gains on an accrual basis, and tax the imputed rent from owner-occupied housing (Coleman, 2017).

\section{Taxation of KiwiSaver}

The income tax treatment of KiwiSaver significantly reduces the returns individuals receive from saving. Income taxes impose a greater tax on future consumption relative to current consumption, creating a bias towards current consumption and discouraging saving. This effect is exacerbated when the compound returns from an individual's KiwiSaver account occur over a long period, as is the case with young people (Neilson, 2018).

The inflation component of interest income is also taxed. As a result, real interest earnings are taxed at above nominal rates. Taken together, an individual with an effective 28\% prescribed investor rate (PIR) who saves for 50 years in KiwiSaver would pay an effective tax rate of 58\% (Financial Services Council, 2013). Indeed, taxes saved over a lifetime as a percentage of retirement saving contributions in New Zealand are the second lowest in the OECD (OECD, 2018). This makes KiwiSaver relatively unattractive compared to investment in owner-occupied housing.

\section{Consequences of New Zealand's tax treatment for owner-occupied housing}

The expenditure taxation of owneroccupied housing since 1989 has incentivised owners to bid up the price of land located near desirable amenities. It has also encouraged households to live in houses that are approximately 25\% higher quality than under a neutral tax system.

The size of newly constructed housing was stable from 1980 to 1988, then increased sharply after the 1989 tax changes, and much faster than in Australia or the United States (Coleman, 2017). This evidence aligns with the theoretical literature. Feldstein (1977) showed that tax incentives favouring housing are capitalised into higher house values, reducing the welfare of future generations.

An example helps to explain how the tax system incentivises owners to bid up
A cap on

maximum contributions and eligibility based on birth date would help to reduce the fiscal costs of transitioning to
this scheme.

the price of housing. I am willing to pay $\$ 20,000$ extra to live in Thorndon instead of Lower Hutt. Thorndon is close to my job and other activities I enjoy doing, with the added benefit of less money and time spent on transport. How much more I am willing to pay to live in Thorndon is inversely related to interest rates. If interest rates were $4 \%$, I would pay $\$ 500,000$ to get a $\$ 20,000$ benefit. $\$ 500,000$ would be the capitalised land value under a neutral income tax system. However, under New Zealand's non-neutral tax system, this value is capitalised into an amount approximately twice as high for conveniently located land (Coleman, 2017). This is particularly evident in Wellington, where a low supply of conveniently located land has led to students and young professionals struggling to find a suitable place to live.

Older New Zealanders have enjoyed higher house prices, which are likely to be at least partly attributable to New Zealand's distortionary tax system. The literature and empirical evidence demonstrate that young people have continued to face artificially high house prices. New Zealand is the only country with an EET scheme for owneroccupied housing and a TTE scheme for retirement savings. Virtually all other OECD countries have an EET scheme for retirement savings (OECD, 2018).

There is no evidence that New Zealand's capital income taxation is not harming young people. On the contrary, it is increasingly difficult for young people to buy their first home. Even if we address supply issues and other problems which contribute to high house prices, the tax system will continue to impose significant costs on young people. Tax system reform would address the intergenerational inequity of the 1989 tax changes.

\section{How can we address this issue?}

Returning to expenditure treatment of KiwiSaver would best address the root cause of the tax distortion, and in turn reduce house prices. EET treatment of KiwiSaver would provide individuals with another tax-advantaged investment, reducing the bias towards owner-occupied housing. This could incentivise people to hold more income in KiwiSaver instead of saving in other ways, such as through a business.

In a scheme where all capital income is taxed at the same rate, this would represent a new distortion. However, as the government currently taxes capital income at different rates, an EET scheme could reduce the proportion of capital income taxed at very high rates by improving average pre-tax returns (Coleman, 2019). An expenditure tax regime for KiwiSaver could reduce the demand for housing and house prices, without sacrificing economic efficiency.

In a scenario where house prices fall by $15 \%$ due to an EET scheme for KiwiSaver, renters and owner-occupiers with limited equity would save on rent and mortgage interest costs. Assume a house costs $\$ 600,000$, and its value appreciates at $1 \%$ each year. Under a TTE scheme, a renter pays $\$ 23,428$ in rent (Coleman, 2017). An owner-occupier with $50 \%$ equity pays $\$ 15,000$ in mortgage interest. If an EET scheme reduced the price of this house to $\$ 510,000$, the renter would pay $\$ 19,914$, while the owner-occupier would pay $\$ 10,838$. This is a $15 \%$ decrease in housing costs for the renter, and a $28 \%$ decrease for the owner-occupier.

This fall in housing costs would make it feasible for young people to find suitable housing. An EET scheme may be seen as regressive (Savings Working Group, 2010). Higher income people would disproportionately benefit from the reduction in tax rates, as they are normally 
able to save more of their income. However, low- to middle-income earners are less likely to be able to invest in lightly taxed assets such as housing, and more likely to invest in highly taxed KiwiSaver accounts (Coleman, 2019). As an EET scheme would reduce tax on KiwiSaver, it may be less regressive than initially thought.

The transition to an EET scheme needs to be effectively managed. The government would experience an initial fall in tax revenue, as it would not receive any revenue when income is first placed into KiwiSaver, nor from compounding returns. However, these costs would be offset by the tax revenue received when individuals withdraw their balances (Coleman, 2019). This transitional cost could be managed by borrowing more or removing the member tax credit (Inland Revenue, 2020). Additionally, a limit on maximum contributions should be set to manage the fiscal cost of the scheme (Tax Working Group, 2018). This will prevent highincome individuals investing all their funds in KiwiSaver to enjoy its tax-advantaged status.

To reduce transitional costs, only those born after a certain date could be eligible to receive expenditure taxation of KiwiSaver (Coleman, 2019). For example, only those born after 1986 could be eligible for expenditure taxation to reflect the average first home purchase age of 31-34 (Wilkes, 2019). Anyone born before 1986 would continue to fall under the old TTE scheme. This would prevent older homeowners benefiting from higher house prices as well as more generous retirement income tax treatment.

Young people have borne the brunt of the artificially high house prices the tax system has contributed to. Homeowners have built larger, higher-quality houses, and bid up the price of conveniently located land. The tax-advantaged status of owneroccupied housing relative to KiwiSaver has incentivised this.

No other country has followed in New Zealand's footsteps after the 1989 tax changes, recognising the significant costs this system imposes on young people. Returning to expenditure treatment of KiwiSaver would be the most direct way to address this issue, as it would provide another tax-advantaged savings vehicle. A cap on maximum contributions and eligibility based on birth date would help to reduce the fiscal costs of transitioning to this scheme. Reforming capital income taxation is crucial to reducing house prices so more young people can purchase their first home.

\section{References}

Coleman, A. (2017) Housing, 'the Great Income Tax Experiment', and the Intergenerational Consequences of the Lease, Economics discussion paper 1709, https://www.otago.ac.nz/economics/otago642975.pdf

Coleman, A. (2019) 'Taxing capital income in New Zealand: an

international perspective', https://www.interest.co.nz/sites/default/files/

embedded_images/Coleman\%20Tax\%20and\%20growth\%20in\%20

NZ\%202019.pdf

Feldstein, M. (1977) 'The surprising incidence of a tax on pure rent: a new answer to an old question', Journal of Political Economy, 85 (2), pp.349-60

Financial Services Council (2013) The Tax Barrier to Retirement Prosperity in New Zealand, Auckland: Financial Services Council, https://www.fsc. org.nz/site/fsc1-dev/files/SuperSize\%20Conference\%202013/ FSC-Taxation\%20and\%20Savings\%20Paper-Final\%20copy.pdf

Inland Revenue (2020) ‘Government contribution', https://www.kiwisaver. govt.nz/new/benefits/goverment-contribution/

Neilson, P. (2018) 'How to fix the over-taxation of retirement savings', https://www. peterneilson.nz/blog/2018/5/13/how-to-fix-the-overtaxation-of-retirement-savings

OECD (2018) 'The tax treatment of retirement savings in private pension plans', policy brief, https://www.oecd.org/daf/fin/private-pensions/ Tax-treatment-of-retirement-savings-Policy-Brief-1.pdf

Savings Working Group (2010) 'Expenditure taxes and savings', https:// treasury.govt.nz/sites/default/files/2010-11/swg-b-ir-ets-27oct10.pdf

Tax Working Group (2018) 'Taxation of capital income and wealth', https:// taxworkinggroup.govt.nz/sites/default/files/2018-05/Taxation-of-capitalincome-and-wealth.pdf

Wilkes, M. (2019) 'Is it better to buy your first home with a stranger rather than your partner?', Stuff, 5 September, https://www.stuff.co.nz/ life-style/homed/houses/1 15463657/is-it-better-to-buy-your-firsthome-with-a-stranger-rather-than-your-partner

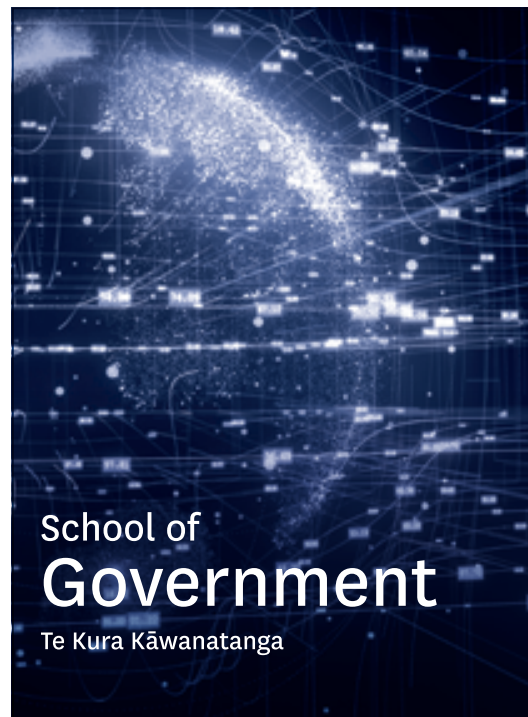

\section{School of Government Brown Bag seminars - open to all}

Join lively, topical presentations and discussions in an informal setting at the School of Government. These Brown Bag sessions are held the first Monday of most months, over lunchtime. Past topics have included:

Intergenerational wellbeing and public policy A visual exploration of video surveillance camera policy and practice The role of financial risk in the New Zealand Primary Health Care Strategy
Strategic public procurement: a research agenda

What role(s) for Local Government: 'roads, rates and rubbish' or 'partner in governance'? Human capital theory: the end of a research programme?

How do we do things?

We would welcome your attendance and/or guest presentation, if you are interested.

Contact us to go on the mailing list for upcoming sessions at sog-info@vuw.ac.nz 